\title{
Poverty, Shame and Ethics in Contemporary China
}

\author{
Lichao Yang and Robert Walker
}

\begin{abstract}
Taking China as a critical case, this article questions recent literature that asserts that shame attached to poverty is both ubiquitous and always problematic. In China, the concepts of shame, loss of face, lian (integrity) and mian (reputation) once provided an ethical framework under which the existence of poverty both indicated ineffective governance and provided individuals in poverty with opportunities to demonstrate virtuous behaviour in coping with life's hardships. Maoist rhetoric went further presenting poor peasants as national heroes albeit the outcome of Maoist policies was often to hurt the most disadvantaged most. Subsequent marketisation has transformed poverty into a manifestation of personal failing with poverty-related shame having the same likely negative consequences as found elsewhere.
\end{abstract}

Keywords: China; poverty-related shame; ethics; morality; governance; marketisation

\section{Introduction}

Walker et al.’s (2013) JSP article on poverty-related shame has stimulated a bourgeoning literature (Sutton et al. 2014; Baumberg, 2016; Patrick et al., 2016; Plantinga et al., 2018) and added the concept of 'shame-proofing' to policy discourse. The growing consensus is that shame is overwhelmingly negative. Felt as psychic pain, poverty-related shame lowers self-worth, leads to social exclusion and low social capital and, by reducing individual agency, may even serve to perpetuate poverty. Consequently, 'shame-proofing' policies, eliminating stigma in their framing, structure and delivery, is increasingly promoted by organisations such as Unicef (2019) and the OECD. 
However, while Walker and colleagues claimed to have identified a universal relationship, others have suggested that it is moderated by time, place, culture and stage of economic development (Roelen, 2017; Jo 2013). China, in this regard, is a critical case. Typically classified as a shame rather than a guilt-based culture, shame traditionally being viewed as positive, rather than a negative, force, underpinning morality used to lead or goad people into behaving in socially acceptable ways. However, China has been fundamentally transformed ideologically, economically, socially and morally over four decades during which 'marketisation' is credited with reducing extreme poverty from 99 per cent to one per cent (Guan, 2014; Wu, 2014). Therefore, the intention in this article is to explore the linkages between ethics, poverty and shame as they have evolved in China in the context of marketisation. While continuities connect market socialism to Maoism and Confucius, the extent, intensity and destructiveness of poverty-related shame have all increased with the advance of marketisation and individualism.

In the West from the time of Emperor Constantine until the Reformation and beyond, the Church administered poverty relief as ‘charity’ (translated from the Greek, agape, love), benevolence dissociated from any concept of rightfulness. However, since the Church relinquished its primacy in providing poverty relief, policy discourse in the Anglo-Saxon world has focussed on personal responsibility, promoting the work ethic and on sorting the 'deserving' from the 'undeserving' as recipients of tax-funded support (Himmelfarb, 1984). In China, until very recently, poverty alleviation has been based, as with the Church, on benevolence, a manifestation of the virtue of the Emperor and subsequently that of the State (Leung and Nann, 1995). However, this has changed due to two neglected consequences of market reform, both associated with growing inequality. They are the deconstruction of moral codes that once applied to both 
governance and social life and the related rise in the salience of poverty-related shame as explained below. The latter is especially important because it arguably intensifies the negative and debilitating effects of poverty while reducing social solidarity necessary to secure improvements in the generosity of social assistance (Walker, 2014).

The article is structured into three main sections. The first makes connections between the Western literature on poverty and shame and traditional Chinese thinking based on Confucius. The concepts of face and loss of face are important in Chinese thought, underpinning both political and personal morality. Moreover, the existence of poverty was once thought to be demonstrable evidence of weak, ineffective and corrupt governance while providing those in poverty with scope to display virtue in coping with the vicissitudes of life.

The second section demonstrates that these traditional moral codes were appropriated and adapted to be consistent with Maoist ideology. Poverty defined in class terms was a mark of status although the collectivist socialist modes of production and social organization created social inequalities that served to undermine the standing of people in poverty.

Finally, the third section shows how, with marketisation, both Confucian and Maoist moral codes have been largely supplanted by an emphasis on individual wealth creation as the principal determinant of social status. In such circumstances, poverty is shameful and lacks potential as a test of virtue. Instead, poverty-related shame serves as a social punishment rather than as a means of promoting personal morality and growth.

The analysis focuses on the dominant values that are generally taken to frame the beliefs and values of most people and which, coincidently, help to distinguish one culture from another Of necessity, evidence presented varies across the three time 
periods with greater availability of empirical data in the later periods when some associations can be drawn between dominant values, public attitudes and behaviour.

\section{Poverty-related Shame and Morality in the Traditional Chinese Thinking}

The interplay between poverty and shame is increasingly recognized internationally. For Noble laureate, Amartya Sen (Sen, 1983), shame lies at the 'irreducible absolutist core’ of the idea of poverty while Walker argues that poverty-related shame results in social withdrawal and a sense of powerlessness that may lessen the effectiveness of antipoverty programs that confer stigma (Walker, 2014). In China too, poverty has long been coupled with shame but in ways different from in the West (Li and Walker, 2017).

\section{Shame and 'Face' as Moral Notions}

It is necessary to explain the Chinese conception of shame before considering the evolution of the poverty-shame nexus. In traditional Chinese culture, shame (most often expressed as chi) is considered to be an ethical concept, framed by Confucianism as the dominant mode of moral and social thought (Fingarette, 1998). It is first and foremost a moral force, an emotion and a human capacity that directs the person inward to selfexamination and motivates them towards morally and socially desirable change (Fingarette, 1998; Li et al., 2004). Shame also has an explicitly social component, namely the negative experience generated by a person's sense of failure to live up to others' expectations which is inherently comparative; the reference point can be others or an imaginary self-evaluation from the perspective of the other. Shabby appearance or disreputable behaviour might equally trigger both social and moral shame.

There are thus many similarities with the predominant conceptualization of shame in the West as a social force that ensures social cohesion and inclusivity through 
encouraging individuals to conform to social norms (Scheff, 2000). While shame is taken to be externally imposed by society, both by individuals and through social institutions, it is also internalized with individuals portrayed as constantly monitoring themselves against a combination of their own aspirations and their perception of others’ expectations ( Tangney et al., 2007). The sociological and psychological consensus in the West is that, although the threat of shame may occasionally deter antisocial behaviour, shaming itself merely imposes pain with minimal change in attitudes or behaviour (Scheff and Retzinger, 1997; Tangney et al., 2007;). Nevertheless, 'naming and shaming' has popular recognition in the West as an appropriate mechanism of social control (Brown et al., 2009).

For Confucius, there was no question as to whether shame worked for society; governance and morality were viewed as being intricately interconnected, largely through the mechanism of shame. Shame was thought to occupy the centre of the moral mind and to be the principal means of regulating and calibrating people's behaviour. Confucian thought equally prioritizes shame as a moral ability; having the facility to sense or feel shame and to exhibit it as a disposition were attributes characterizing the model person (Seok, 2015). Indeed, Mencius, famous pupil of Confucius' grandson, Zisi, declared that 'An individual without a sense of shame was no longer human' while Confucius himself argued that people knowing shame would live upright lives and proposed that before punishment, people making mistakes should first be taught to sense shame. ${ }^{\mathrm{i}}$

The centrality of shame in Confucian thought and Chinese culture is illustrated by the more than 100 shame-related expressions identified in the Chinese language (Li et al., 2004). But, despite the refined understanding that this plethora of expressions suggests, 
the most common manifestation of shame is 'loss of face' which is, in turn, closely associated with the concepts of lian and mian (Ho, 1994; Hu, 1944).

Mapped into Western thinking, mian and lian are perhaps best considered to be components of shame, manifest as loss of face. Mian refers to a reputation achieved through moral behaviour and social success. It can be acquired through personal effort and/or social influence but its acquisition and retention are necessarily always conditional on an individual's external environment. Lian denotes the respect of the group for an individual who has fulfilled their moral obligations regardless of the hardships involved and who 'under all circumstances shows himself a decent human being' (Hu, 1944). As such, it is 'a social sanction for enforcing moral standards and an internalized sanction' and, in traditional Confucian society, it both reflected and shaped society’s confidence in the integrity of an individual's moral character (Hu, 1944). Whereas mian is divisible, able to be accumulated and lost in increments, lian is generally considered to be indivisible: an individual has lian or they do not. Both mian and lian belong to a larger set of concepts including honour and respect that have received extensive research attention (Cheng, 1986; Ho, 1994; Hu, 1944).

Loss of face is the shaming of an individual by the group in response to their immoral or antisocial behaviour. To have reduced, low or no mian is to lose or to fail to acquire a reputation through success in life, while to have no lian is to have no integrity. Moreover, while a person is not necessarily expected to strive to gain face through increased mian, 'losing [lian] is a serious matter' that is likely variously to affect their 'ability to function effectively in society' (Ho, 1994). Avoiding loss of face is therefore more closely associated with maintaining lian than with seeking to gain the respect of others (mian). 
To recap, in Confucian culture, shame is primarily a moral tool. Through the pressure to retain face - to acquire lian and high mian - shame is considered to play an important role in insuring individuals' moral integrity, maintaining their self-respect and fostering a well-ordered society.

\section{Poverty, Morality and Good Governance}

Under Confucianism poverty serves as a litmus test of virtue, but the test differs between ruler and ruled. For the ordinary individual, poverty itself carries no stigma; virtue is demonstrated through the acceptance of their lot, be it poverty, and by behaving morally, retaining lian, despite financial pressures to do otherwise. For rulers however, the existence of poverty is itself a source of shame for it is taken as evidence of poor governance and therefore of moral failing:

When the dao prevails in a state, to be poor and of low rank is shameful; when the Dao does not prevail in a state, to be wealthy and of high rank is shameful (Waley, 2005). ${ }^{i i}$

Claims to morality as the foundation of Chinese governance have been made for at least 3,500 years with rulers deemed to be responsible for the well-being of their people. When the Shang Dynasty (1600-1100BC) was overthrown and replaced by the West Zhou Dynasty (1100-771BC), the incoming ruler, referring for legitimacy as was traditional to the so-called 'Mandate of Heaven', explained that, 'heaven does not favour anybody; only morality makes Heaven trust you’ (Deng, 2011).

Confucius further elaborated the concept of good governance arguing that the ruler's first duty should be to exemplify sound moral conduct displaying benevolence, filial piety, faithfulness, courtesy, integrity, and frugality (Tong, 2011). Hence, the legacy of Emperor $\mathrm{Han} \mathrm{Wu}$, iii in accepting Confucianism as the official ideology, was that all 
subsequent emperors were expected to set the highest moral example for their subjects. Beneath them, government officials at all levels were required not only to be behave morally but also to be moral and ideally to enhance their morality over time. Informed by this history, Tong and Shue both argue that, within Chinese culture, legitimacy of any political regime is grounded on the morality of the political elite (Shue, 2010; Tong, 2011:43). Good governance prevented poverty and excessive inequality, the former believed to be a cause of crime and the latter a source of social unrest, while administering to the needs of the poor demonstrated the benevolence of the state (Solinger, 2015).

While the existence of poverty evidenced bad government and, for rulers, meant loss of lian, it offered a person in poverty scope to demonstrate lian. Confucius explains:

Wealth and high rank are what people desire; if they are attained by not following the dao, do not dwell in them. Poverty and mean rank are what people hate; if they are attained by not following the dao, do not depart from them (Waley, 2005).

Thus, tempted to steal or protest, persons experiencing poverty can resist temptation, accept their fate and consequently exhibit lian, finding peace and happiness in pursuing a virtuous life. By so doing, they ease the task of government and contribute to perpetuating the status-quo. Their morality, lian, protects rulers against further loss of face (mian); having allowed inequality and poverty to occur, the ruling elite avoid additional shame accruing from social unrest and possibly the total breakdown of social order.

Equally, under Confucian rubrics, rulers are to be judged by their performance. Policy failure, the existence of poverty for example, can be equated with moral failure implying a loss of lian. With political performance intrinsically linked to morality, 
politics itself is moralized and political criticism inevitably becomes moral criticism (Lin, 1992; Tong, 2011). Good governance was recognized by Confucius to rely heavily on the ethical standards of political elites who were charged to exhibit benevolence to the people, to practice self-control and to pursue the practice of cultivating moral character (xiushen).

\section{Poverty, Shame and Politicalized Morality under Maoist Socialism}

Whereas politics is heavily moralized in Confucian society, morality became highly politicalized during China’s socialist era with profound implications for the framing of poverty and shame. After Mao Zedong's declaration of the founding of the People’s Republic of China on 1 October 1949, the Chinese Communist Party (CCP) adapted Marxist-Leninist doctrine, monopolizing economic power through a planned economy and implementing a collective redistributive system based on the premise that 'poor' and 'middle' peasants had the capability to lead the country. In the peasants' name and based on these two monopolies, China was governed under Mao socialism as a de facto one party authoritarian state.

Maoist doctrine ostensibly both valued and sought to liberate people from poverty. Poverty was portrayed as being the result of exploitation and those in poverty were presented as belonging to the vanguard of the continuing revolution: 'mud stuck with mud makes the wall; the poor help the poor become king' (Zhou, 2004). Society was also actively organized politically according to the class label system implemented in the early 1950s (Chan et al., 1984). 'Poor' and 'middle peasants' together with workers and revolutionary cadre constituted the 'proletariat', on Mao’s estimate accounting 95 per cent of the population (Meisner, 1971). These were juxtaposed against rich peasants, landlords and capitalists. Mao accorded the former the special revolutionary virtue of 
being 'poor and blank'. Poverty, he argued, gave 'rise to the desire for changes, the desire for action and the desire for revolution' while 'on a blank sheet of paper free from any mark, the freshest and most beautiful characters can be written’ (Mao, 1958); free from vested interests, people in poverty were also free to welcome and facilitate radical change.

Thus, the widespread poverty became a symbol of virtue: 'the poorer you are, the more glorious you become' (Fan, 2007). Moreover, there is evidence that poor and middle peasants were initially favoured in village resource allocation (Brown and Johnson, 2015). But, economic and status inequalities, especially those between urban and rural areas, deepened during the Maoist era as a result of the imposition of household registration (hukou), the centralized employment system and politically inspired campaigns (Brown and Johnson, 2015; Li and Sicular, 2014). As a consequence, the doctrinal slogan that 'the poorer, the more virtuous' was undermined and replaced by a stratification system that rewarded demonstrable commitment to the Party.

The hukou system divides the Chinese population into 'agricultural' and 'nonagricultural' sectors and rural and urban identities, determining one’s access to decent jobs, housing, education, health care, and even the right to move to a city, thus condemning many rural residents to remain as poor peasants. (Wu and Treiman, 2004).

The centralized dual system of employment further differentiated privileges. Individuals were assigned either to rural community-owned collectives (nongye da jiti ) or to state-owned urban work units (danwei) where they had to remain life-long unless relocated by relevant authorities (Liu, 2010; Yan, 2010). In rural collectives, food and other supplies were allocated based on the work contribution of residents while within the urban danwei sector, workers received wages, topped up by comparatively generous 
occupational benefits provided through the workers’ danwei. Under Maoist socialism, everyone was economically dependent on their work unit or collective socioeconomically, politically dependent on state-sponsored management, and personally dependent on the Communist cadres (Walder, 1988). But, counter to Maoist aspiration or rhetoric, the dual system placed poor peasants at the bottom of the occupational hierarchy and offered them the least reward for their labour.

Ironically, the poorest segments of the population were further disadvantaged by the Maoist morality of class struggle, revolution, and self-sacrifice to achieve a Communist utopia (Ci, 1994; Yan, 2010). Maoist morality was personified in the form of model citizens, the 'good soldiers of Chairman Mao’ embodying two sets of priorities. First, moral individuals prioritized their ultimate loyalty to the party-state over their filial duties to their parents and family and, secondly, they prioritized other people's interests over their own and the public interest over that of individuals (Yan, 2010). The parallels with Confucian thought are marked. Under Maoist socialism, the feudal ruler was replaced by the party-state that, acting in the name of the masses, demanded individual devotion to the collective rather than to the family and to the state, instead of the Emperor while, unlike Confucius, failing to acknowledge of the power of political elites. Instead, the Party, informed or justified by public consultation, the so-called 'the mass line (qunzhong luxian), presumed that all its actions, typically implemented as political, ideological and economic campaigns rather than legislation, were in the interests of the people and hence benevolent irrespective of their impact on individual citizens.

Both mian and lian were initially decoupled from economic success under Maoist socialism and attached to their official class label. Classified as an anti-revolutionary or a landlord, a person lacked lian and their ability to function effectively in society was 
severely constrained. Because a superior class/identity label needed to be reconfirmed through demonstrable political engagement, and inferior status could be reversed through political performance, a person's mian and lian were tied to political approval of a person's behaviour.

However, during the Mao era, face became increasingly determined by hukou and employment. Transforming one's hukou status from rural to urban, and one’s working identity from worker to cadre, each demonstrating hard won Party approval, became important mechanisms of upward social mobility conferring mian and demonstrating lian (Wu and Treiman, 2004). Agricultural hukou holders and workers were mostly ignored in elite Chinese discourse on development or else portrayed as 'poor', 'backward’, or 'low quality’, ‘a drag on modernization’ (Jacka, 2013). Maoist social institutions thus became the major mechanisms of social stratification with high status being dependent on behaviour deemed to be politically desirable (mian) and by implication moral (lian). Ironically, the poor rural peasants, initially lauded as 'virtuous', came generically to lack status, mian and lian.

\section{Ethics, Poverty and Policy under a Socialist Market Economy}

The radically different strategy adopted by Chinese governments in pursuit of economic growth and social stability since Mao has been well documented elsewhere (Allen et al., 2005; Meijun, 2005; Lin, 1992; Montinola et al., 1995). In summary, the collectivist system of agriculture has been largely dismantled and there has been a major retreat from enterprises directly owned by the state. In its place, entrepreneurship has been encouraged, legal reforms have facilitated private ownership of assets and the political rhetoric has shifted towards praising the accumulation of personal wealth. Quite soon after the death of Mao, his vision of socialism was being presented officially as 
romantic, even irrational, and incompatible with the demands of modernization. The old Maoist slogan referring to the forward march of socialism (yiqie xiang qian kan, 一切向 前看) was commonly parodied with talk of the forward march of money (yiqie xiang qian kan, 一切向钱看), money above everything (Dutton, 2000). Rather than moral exaltations to altruism, to prioritize public rather than self-interest as demanded under Confucian and Maoist thought, Deng Xiaoping and his successors have offered incentives to promote individualistic advancement: money bonuses, responsibility systems and other contractual arrangements (Ibid).

The net result has been substantially to change the ethical foundations of public life and to reframe the conceptualization of poverty and its moral basis, shifting responsibility from rulers, community and the state towards individuals. There has been accommodation to inequality, that both Confucius and Mao saw as detrimental to social stability, as a necessary consequence and driver of competition, while society’s weakest have been exposed to denigration and the role of shame altered from a positive moral force to a potentially divisive and destructive social process.

If China's rapid economic growth and the dramatic decline in absolute poverty can be attributed to the economic reforms associated with marketisation, so too can the equally dramatic rise in inequality. The increase in the Gini coefficient, the most commonly used indicator of household income inequality, from 0.30 in 1980 to 0.55 in 2012 is almost unprecedented (Xie and Zhou, 2014). Of course, during the Maoist era, income differentials were very small compared to those in many other countries, a product of an explicitly egalitarian ideology but also of long periods of relative economic stagnation.

The reasons for rising inequality can be traced to policies set in place very early in the post Mao period (Sun and Guo, 2013). For example, the process of opening China to 
foreign investment was initially permitted solely in specifically designated Special Economic Zones and later in 14 coastal cities that opened for foreign investors in the mid-1980s (Andersson et al., 2013). These centres have generally continued to prosper drawing in investment and creating new employment opportunities. As important, as a contributor to growing inequality, has been the large scale, rural-urban migration of labour necessary to meet the demands of the growth in industry and commerce. While migrants have often benefitted from wages higher than they could have received in their villages, the vast majority are still tied to their villages by their agricultural hukou, retain their rural identity, earn less than their urban counterparts and are excluded from social welfare provisions available only to those with an urban hukou (Chen and Hamori, 2013; Fan, 2008). Incomes and profit in rural areas have fallen further in relative terms due to shrinkage of the agricultural sector as a whole and heightened competition for the few remaining local waged opportunities. Indeed, the rural households without migrant workers or other alternative waged work now have the lowest average incomes. Moreover, rural hukou holders including rural migrants and residents suffer lowly status as well as low income (Jacka, 2013).

Aware of the growing inequalities, and possibly fearful of the social instability that might result, the government in the 1990s began to roll out to rural areas a variant of the Minimum Living Standard Guarantee (dibao) that had first been implemented in Shanghai. This was to complement the rural 'five guarantee household' (wubao) scheme that was well-established but comparatively small in scale and targeted exclusively at elders without family support. Dibao provides a means-tested supplementary payment for low-income families that is administered through villages. Implemented nationally only in 2007, dibao is now the world's largest social assistance system with 60.7 million beneficiaries (Ministry of Civil Affairs, 2017). Heavily 
criticized because of poor targeting, dibao was periodically reviewed and redesigned in the following years but still has limited impact on poverty rates and only marginally reduces income inequality. ${ }^{\text {iv }}$

The shift from Maoist collectivism to marketisation was accompanied by a sustained re-education campaign designed to promote and legitimate entrepreneurial individualism. In so doing, and the evidence suggest considerable success (Yan, 2003), a new moral order was created very different from either Confucianism or that associated with Maoism. Under Deng Xiaoping, in the late 1970s, making money was deemed to be more important than anything else: 'the black cat or white cat, it's a good cat if it catches mice’ (Cao, 1995). However, the excesses of rampant greed were already evident by 2004 when, acknowledging widespread corruption, President $\mathrm{Hu}$ Jintao included 'regard honesty and trustworthiness as honourable and sacrificing ethics for profit as shameful' among the eight basic tenets of a 'socialist harmonious society' (Lin, 2017).

Complementing the positive emphasis on individual wealth making is a new negative portrayal of poverty. While the Maoist framing was that poverty was a worthy sacrifice made to benefit the continuing revolution and future national prosperity, this has been replaced by group denigration as evidenced by the discourse of suzhi (Lin, 2017). Suzhi refers to human quality, anatomical, moral and behavioural. Once taken to mean the characteristics of anything, by the 1970s it referred to the innate physical, psychological and intellectual characteristics of the human body. Subsequently its meaning has changed again to embrace acquired characteristics and the extent to which these qualities are fully exploited in terms of ideology, moral stance and conduct (Jacka, 2009; Kipnis, 2003). First used in this way by party officials with respect to population and education policy, poverty, in the context of marketisation, is no longer attributed to 
poor governance or to revolutionary social sacrifice but to 'low suzhi', be it of individuals or social and ethnic groupings. Poverty is declared to be the result of poor work ethic, lack of ability, and/or other character defects (Hunt, 1996). Hence, diligence was included as an honourable tenet of the ‘socialist harmonious society' and indolence as shameful.

Returning to the concept of shame and to lian and mian, marketisation has consistently boosted the relative importance of mian and undermined lian. Mian, the reflection of social status, has come to be interpreted socially not as moral worth or doing one’s social duty with respect to emperor or party, but as personal wealth and conspicuous consumption. In the Confucian world, and even during the Maoist era, lian tended to be prioritized; placing others first, being a good citizen or a good civil servant were demonstrably the basis of a person's social status, their public face. Post marketisation, it often seems that accumulated wealth alone buys social status. This creates a dilemma for government officials. Often lowly paid, they need to choose between the Confucian and Maoist codes that prioritize sacrifice in order to serve the people and the new socio-economic reality of pursuing 'their own interests in competition with others in an increasingly capitalistic economic order' (Wang, 2002). It also means that poverty is no longer regarded as a positive sacrifice nor viewed as being morally neutral (or even favoured by the superior person to demonstrate their morality): rather it is invariably tantamount to loss of face.

Evidence of these changes in the perception of poverty since marketisation is accumulating rapidly (Yan, 2010). China is exceptional in the proportion of people (58\%) believing poverty to be caused by 'laziness and lack of will-power' (exceeded only by Puerto Rico 72\%, the Philippines 65\%, and USA 62\%) and, while numbers may possibly have fallen, they remain high in rural areas (Walker, 2014; Xun, 2015). 
Blamed in this way, accused of low suzhi, it is unsurprising that people in poverty feel ashamed. Chen et al. have identified poverty-related shame as one of four stressors in the lives of low-income elders in Beijing (alongside lack of resources, ill-health and challenge of caring for others) (Chen et al., 2017). Leaving aside material deficits, they often believed themselves to be socially and morally inferior and to be despised by others leading them to avoid social contact and to lower their expectations in life. Similarly, poor villagers in both rural Shanxi Province and south central China are reported to be shunned by their neighbours and village cadres who explained the existence of poverty in terms of low suzhi, laziness and irresponsibility. Where dibao and wubao are claimed by people on account of poverty, rather than received for reasons other than need, they too are stigmatized and confer shame on recipients: loss of mian due to demonstrable lack of resources; lack of lian because poverty and dibao receipt are attributed to personal deficiencies, low suzhi (Li and Walker, 2017).

Negative attitudes towards poverty, dibao and wubao are further fuelled by rising inequality, increasingly divergent class interests and geographical separation (Akay et al., 2012; Li and Walker, 2017). Indeed, some have argued that there is a growing resentment and an increased antagonism between urban and rural, rich and poor, that is linked to corruption, inequality and increased discrimination against people experiencing poverty (Wang, 2002). Certainly, the shift in political rhetoric from explaining poverty in structural terms towards individualistic explanations based on personal competence and responsibility creates space for the development of cultures of blame and othering similar to those well documented in the West (Handler and Hasenfeld, 1997; Lister, 2004). Likewise, resentment is understandable given widespread corruption and the commonly held belief that economic success and the receipt of government benefits are often products of corruption (Tong, 2011). Both 
resentment and othering have been reported in recent qualitative studies of dibao recipients and, in urban areas, a discourse reminiscent of the aformentoned deserving/undeserving debate in some Western countries (Chen et al., 2017; Wen \& Ngok, 2018).

Ironically, corruption allied to institutional alienation (the mismatch between the stated goals of policy and its actual functioning) sometimes protects dibao from stigma and differentiates it from poverty. The 2014 national reform of dibao was part of Chairman Xi's avowed intent to crack down on 'tigers and flies', that is, high-level officials and local civil servants alike, the belief being that dibao was being diverted for personal and family gain (Golan et al., 2015). That said, people illicitly receiving dibao sometimes report taking pride in their status as recipients which demonstrates their influence, guanxi, within the local community. Equally resentment amongst those denied access to dibao is tempered by envy and regret that they themselves lacked the necessary guanxi (Li and Walker, 2017).

Turning to institutional alienation, there is much evidence that dibao has tacitly been co-opted as a tool of village governance with the goal of maintaining social stability rather than tackling poverty. Hence, in some localities dibao is administered as a universal old age pension rather than as a benefit targeted on poverty; this avoids the need for means tests seen as difficult to implement and socially divisive but means that many of the poorest villagers receive no assistance. Elsewhere dibao has been used explicitly to 'buy' political support for local cadres, to 'buy-off' 'trouble-makers' and potential protestors, and to build social cohesion by universalizing access through the use of waiting lists and inclusion criteria that do not prioritize low income (Li and Walker, 2017). 
Ethically, the result is confused. Local cadres do not address poverty as intended, something that would have been shameful according to Confucian and Maoist principles. Nevertheless, social stability is maintained (at least in the short term), eliciting approval (mian) from the political hierarchy albeit as a result of maladministration which, under Confucian rubrics, would have been sufficient to cause the loss of lian. Turning from government officials to beneficiaries, receipt of dibao may contribute positively to mian through added income and social recognition, and positively to lian to the extent that recognition equates with the perception of worthiness. For those receiving dibao illicitly and knowingly, mian may rise with increased income and because of their demonstrable social influence, guanxi; but whereas in the past lian would have been expected to fall because of impropriety this is now less often the case because 'the colour of the cat no longer matters'. For those remaining in poverty, the outcome is crushing. They are no longer accorded mian, as nominally they were under Mao, nor lian as Confucius would have offered had they demonstrated virtue. Instead, they are blamed for their own plight and accused of low suzhi. If they do not even receive dibao, they are further denied social recognition.

\section{Conclusion}

Western literature is increasingly implicating shame as a negative feature in the experience of poverty, one that may even serve to prolong spells of poverty by causing a loss of confidence and agency and reduced social capital. While western psychologists associate shame with social isolation, loss of agency, anger and despair, traditional Chinese thought, strongly influenced by Confucian philosophers, conceptualizes shame, low mian (status) and lian (goodness) to be essential tools of social governance and stimuli for personal growth. The threat of shame encouraged good governance, signified 
not least by the absence of poverty or by proactive attempts to reduce it. In parallel, a person's response to poverty, stoicism, diligence and resistance to temptation, provided a measure of their morality.

Confucian ideas may always have existed as ideals rather than as attainable directives but now they seem largely absent from contemporary debates on poverty (see Table 1). While Mao appropriated some Confucian ideals, including prioritizing collective interests over individual ones and owing ultimate loyalty to the ruler, taken to be the Party, Confucian thought was generally considered reactionary and to be eradicated. Morality was instead defined in terms of revolutionary fervour and commitment to the Party. Rhetorically poorer peasants were held up as people of virtue who stood to gain under the socialist and communist society that Mao envisaged and did initially benefit from land reform. However, 'poor peasants’ were frequently viewed merely as reliable allies in winning over others to support the revolutionary cause (Mao, 1955). Moreover, while the collectivist and danwei systems offered various types of mutual social welfare, albeit often elementary in form, their rigidities and that of hukou often served to disadvantage the very poorest. People experiencing poverty existed in very large numbers throughout the Maoist period and suffered more than most from the frequent famines, campaigns, policy and failures of the time (Nee, 1991; Tsui, 1991).

Table 1. Poverty and shame over time

\begin{tabular}{llll}
\hline Era & Qualification & & \multicolumn{2}{c}{ Impact of poverty on shame } \\
& & Mian & Lian \\
\hline Confucius & Ruler & Negative & Negative \\
\cline { 2 - 3 } & Ruled & Neutral & Neutral to positive \\
\hline
\end{tabular}




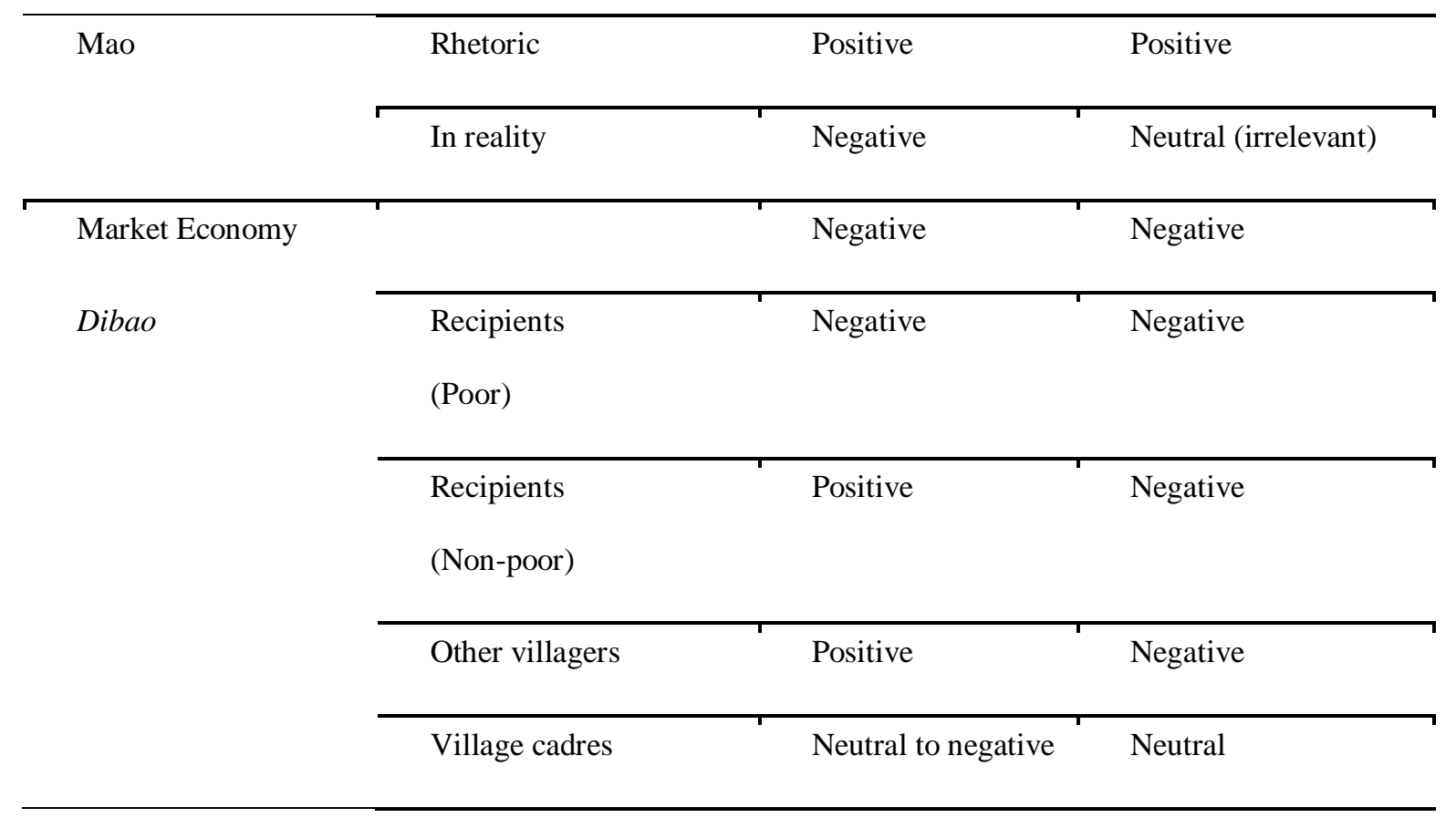

What little Confucian thinking on the morality of poverty survived the Maoist period has been all but been extinguished since. Slogans such as 'let some people get rich first' and 'to get rich by hard work is glorious', and the economic policies that accompanied them, have removed much of the economic and social mutuality that characterized the Maoist period. The 'market socialism' and individualism that have replaced social mutuality have been associated with a prolonged period of high growth and falling poverty rates, albeit accompanied by dramatic increases in inequality that may yet pose threats to social stability. Together these have fundamentally changed the morality of poverty. Previously seen as a product of bad governance or class exploitation, poverty is now considered to be a matter of individual fault and failure, indicative of low suzhi. People in poverty are thus lacking both mian and lian and for the most part structural constraints on people escaping poverty prevent loss of face from having any constructive moral purpose.

With a decline in mutuality and greater inequality creating divergent sectional interests and resentment, people in poverty are increasingly likely to be subject to 
discrimination and stigmatization (Kipnis, 2003; Li and Walker, 2017). While shame usually lessens agency, it sometimes provokes anger that could further erode social solidarity (Wang, 2002). Moreover, policies that succeed publicly in targeting people in poverty are themselves likely to become stigmatized through their association with poverty and to add to the stigma experienced by recipients. That this has not happened more already is probably due to the poor targeting of benefits such as dibao, for these have frequently been commandeered to foster social cohesion and minimize social instability instead of addressing poverty per se.

To return to China as a critical case, adopting the long lens of history suggest that Walker's universalistic thesis requires modification because in China poverty has not always been shameful. In Confucian times, poverty was 'a litmus test of virtue'; - in principle at least - people in poverty could demonstrate their virtue by behaving morally in the most arduous circumstances. Subsequently, Maoist rhetoric presented poverty not as shameful but as a virtue; 'poor peasants' were promoted as leaders of a continuous revolution, poverty being their sacrificial contribution to China's positive future. Finally, with marketisation, poverty has become indicative of failure, personally shameful since everyone is expected to try to become rich. The existence of poverty is no longer a means of shaming government that simultaneously offers a stimulus to personal moral development. Instead, China is added to the list of countries in which the poverty-shame nexus simply adds to the suffering of people in poverty.

\section{References}

Akay, Alpaslan, Oliver Bargain, and Klaus Zimmermann. (2012), 'Relative concerns of ruralto-urban migrants in China', Journal of Economic Behavior \& Organization, 81:2, 421-441. 
Allen, Franklin, Jun Qian, and Meijun Qian. (2005), 'Law, finance, and economic growth in China', Journal of financial economics, 77: 1, 57-116.

Andersson, Fredrik, David Edgerton, and Sonja Opper. (2013), 'A matter of time: revisiting growth convergence in China', World Development, 45, 239-251.

Baumberg, B. (2016) The stigma of claiming benefits: a quantitative study, Journal of Social Policy, 45(2): 181-199

Bian, Yanjie (2002), 'Chinese social stratification and social mobility', Annual Review of Sociology 28:1, 91-116.

Brown, Jeremy, and Matthew Johnson. (2015), Maoism at the Grassroots: Everyday Life in China's Era of High Socialism. Cambridge: Harvard University Press.

Brown, Milton, Marsha Linehan, Kathryn Comtois, Angela Murray, and Alexander Chapman. (2009), 'Shame as a prospective predictor of self-inflicted injury in borderline personality disorder: A multi-modal analysis', Behaviour research and therapy, 47:10,815-822. Cao, Lan. (1995), The Cat That Catches Mice: China's Challenge to the Dominant Privatization Model. Brook. J. Int'l L. 21, 97.

Chan, Anita, Richard Madsen, and Jonathan Unger. (1984), Chen Village: The Recent History of a Peasant Community in Mao's China. University of California Press.

Chen, Guifu, and Shigeyuki Hamori. (2013), Rural labor migration, discrimination, and the new dual labor market in China. Springer Science \& Business Media.

Chen, Yan-yan, Robert Walker, and Liu Hong. (2017), 'Selective experiences of older adults in poverty in urban China and the role of social policy', Asian Pacific Journal of Social Work and Development, 28:1, 1-14.

Cheng, Chung-Ying. (1986), 'The concept of face and its confucian roots', Journal of Chinese Philosophy, 13:3, 329-348. 
Ci, Jiwei. (1994), Dialectic of the Chinese revolution: From utopianism to hedonism. Stanford University Press.

Deng, Zhenglai. (2011), Reviving legitimacy: Lessons for and from China. Lanham: Lexington Books.

Dutton, Michael. (2000), 'The end of the (mass) line? Chinese policing in the era of the contract', Social Justice, 27: 2, 61-105.

Fan, Cindy. (2008), China on the Move: Migration, the State, and the Household. London: Routledge.

Fan, Maureen. (2007), Cashing in on communism. The Washington Post.

Fingarette, Herbert. (1998), Confucius: The secular as sacred. Waveland Press.

Golan, Jennifer, Terry Sicular, and Nithin Umapathi. (2015), 'Unconditional Cash Transfers in China: An Analysis of the Rural Minimum Living Standard Guarantee Program', Policy Research Working Paper No. 7374. World Bank, Washington, DC.

Handler, Joel, and Yeheskel Hasenfeld. (1997), We the poor people: Work, poverty, and welfare. Yale University Press.

Himmelfarb, G. (1984) 'The idea of poverty: England in the early Industrial Age', History Today, 34(2): 23-30.

Ho, D.. (1994), 'Face Dynamics: From Conceptualization to Measurement', In The Challenge of Facework: Cross-Cultural and Interpersonal Issues, edited by Ting-Toomey, 269-286. Albany: State University of New York Press.

Hu, Hsien (1944), "The Chinese concept of 'face"', American Anthropologist, 46, 45-64. Hunt, Matthew (1996), 'The individual, society, or both? A comparison of Black, Latino, and White beliefs about the causes of poverty', Social Forces, 75, 293-322. Jacka, Tamara. (2009), 'Cultivating citizens: Suzhi (quality) discourse in the PRC', Positions, $17: 3,523-535$. 
Jacka, Tamara. (2013), 'Chinese discourses on rurality, gender and development: a feminist critique', Journal of Peasant Studies, 40:6, 983-1007.

Kipnis, Andrew. (2003), 'Anthropological Approaches to Self in Contemporary China', The China Journal, 50, 127-132.

Jo, Y. (2013) Psycho-social dimensions of poverty: When poverty becomes shameful, Critical Social Policy, 33(3): 514-531.

Leung, Joe C. B. and Nann, Richard C. (1995), Authority and Benevolence: Social Welfare in China, Hong Kong: Chinese University Press.

Li, Jin, Lianqin Wang, and Kurt Fischer. (2004), 'The organisation of Chinese shame concepts?' Cognition and Emotion, 18:6, 767-797.

Li, Mianguan, and Robert Walker. (2017), 'Shame, stigma and the take-up of social assistance: Insights from rural China', International Journal of Social Welfare, 26: 3, 230-238.

Li, Shi, and Terry Sicular. (2014), 'The distribution of household income in China: Inequality, poverty and policies', The China Quarterly, 217, 1-41.

Lin, Delia. (2017), Civilising citizens in post-Mao China: Understanding the rhetoric of suzhi, Abingdon: Taylor \& Francis.

Lin, Justin. (1992), 'Rural reforms and agricultural growth in China', The American Economic Review, 34-51.

Lister, Ruth. (2004), Poverty: key concepts, Cambridge: Polity.

Liu, Yu. (2010), 'Maoist Discourse and the Mobilization of Emotions in Revolutionary China', Modern China, 36:3, 329-362.

Mao, Zedong. (1955), "The lesson of the 'Middle-Peasant Co-operative’ and the 'Poor-Peasant Co-operative' in Fuan County", The Socialist Upsurge in China's Countryside.

Mao, Zedong. (1958), 'Introducing a co-operative', Selected Readings from the Works of Mao Zedong, 499-501. Beijing: Foreign Languages Press. 
Meisner, Maurice. (1971), 'Leninism and Maoism: Some Populist Perspectives in MarxismLeninism in China', The China Quarterly, 45, 2-36.

Montinola, Gabriella, Yingyi Qian, and Barry Weingast. (1995), 'Federalism, Chinese style: the political basis for economic success in China', World Politics, 48: 1, 50-81.

Nee, Victor. (1991), 'Social inequalities in reforming state socialism: between redistribution and markets in China', American Sociological Review. 267-282.

Patrick, R. (2016) Living with and responding to the 'scrounger' narrative in the UK: exploring everyday strategies of acceptance, resistance and deflection. Journal of Poverty and Social Justice, 24(3): 245-259.

Plantinga, A., Zeelenberg, M., and Breugelmans, S. (2018). Poverty and Shame in the Netherlands. https://doi.org/10.17605/OSF.IO/UW3KS

Roelen, K. (2017) Shame, Poverty and Social Protection. Brighton: IDS Working Paper 489. Scheff, Thomas J. (2000), 'Shame and the social bond: A sociological theory', Sociological Theory, 18:1, 84-99.

Scheff, Thomas and Suzanne Retzinger. (1997), 'Shame, anger and the social bond: A theory of sexual offenders and treatment', Electronic Journal of Sociology 3:3, 1198-3655.

Sen, Amartya. (1983), 'Poor, relatively speaking', Oxford economic papers 35: 2, 153-169.

Seok, Bongrae. (2015), 'Moral Psychology of Shame in Early Confucian Philosophy', Frontiers of Philosophy in China, 10: 1, 21-57.

Shue, Henry. (2010), "Do We Need a 'Morality of War' ?" , In Just and Unjust Warriors: The Moral and Legal Status of Soldiers. Edited by David Rodin \& Henry, Oxford: Oxford University Press.

Solinger, Dorothy J. (2015), 'Three welfare models and current Chinese social assistance: Confucian justifications, variable applications', The Journal of Asian Studies 74(4): 977-99. 
Sun, Wanning, and Yingjie Guo. eds. (2013), Unequal China: The Political Economy and Cultural Politics of Inequality, London: Routledge.

Sutton, E, Pemberton, S, Fahmy, E and Tamiya, Y (2014) 'Stigma, shame and the experience of poverty in Japan and the United Kingdom', Social Policy and Society, 13(1): 143-154.

Tangney, June Price, Jeff Stuewig and Debra Mashek. (2007), 'Moral emotions and moral behavior', Annu. Rev. Psychol., 58, 345-372.

Tong, Yanqi. (2011), 'Morality, benevolence, and responsibility: Regime legitimacy in China from past to the present', Journal of Chinese Political Science, 16: 2, 141-159.

Tsui, Kai Yuen. (1991), "China's regional inequality, 1952-1985", Journal of Comparative Economics, 15:1, 1-21.

https://www.unicef-irc.org/article/1894-universal-child-grants-conference-highlights-power-ofevidence-informed-policies.html Walder, Andrew (1988), Communist Neo-traditionalism: Work and Authority in Chinese Industry, University of California Press. Waley, Arthur. (2005), The Analects of Confucius, Psychology Press. Walker, Robert. (2014), The Shame of Poverty. USA: Oxford University Press. Walker, Robert et al. (2013), 'Poverty in Global Perspective: Is Shame a Common Denominator?’ Journal of Social Policy, 42(2): 215-233.

Wang, Xiaoying. (2002), "The post-communist personality: the spectre of China's capitalist market reforms", The China Journal, 47, 1-17.

Wen, Z., \& Ngok, K. (2018), 'Governing the poor in Guangzhou: Marginalization and the neoliberal paternalist construction of deservedness', China Information. https://doi.org/10.1177/0920203x18786876 
Wu, Xiaogang, and Donald Treiman. (2004), 'The household registration system and social stratification in China: 1955-1996', Demography, 41: 2, 363-384.

Xie, Yu, and Xiang Zhou. (2014), "Income inequality in today’s China", Proceedings of the National Academy of Sciences, 111: 19): 6928-6933.

Xun, Zhou. (2015), Preference for Redistribution and Inequality Perception in China: Evidence from the CGSS 2006.

Yan, Yunxiang. (2003), Private Life under Socialism: Love, Intimacy, and Family Change in a Chinese village, 1949-1999. Stanford University Press.

Yan, Yunxiang. (2010), 'The Chinese path to individualization', The British Journal of Sociology, 61:3, 489-512.

Zai, J. (2015), Taoism and Science: Cosmology, Evolution, Morality, Health and more. Ultravisum.

Zhiping, Diao, Shamala Paramasivam, and Ilyana Jalaluddin. (2015), 'Influence of Ancient Chinese Li Culture on Modern Chinese Politeness Principles', Language \& Communication, $2: 1,15-25$.

Zhou, Erfu. (2004), "Shanghai’s Morning", in Erfu Zhou (eds). Beijing: Culture and Arts Publishing House.

\section{Notes}

${ }^{\mathrm{i}}$ All citations of Mencius are taken from Faber 2012.

${ }^{\text {ii }}$ Dao is generally taken to mean the ideal way or path of perfection Zai, J (2015)

Taoism and Science: Cosmology, Evolution, Morality, Health and more: Ultravisum..

iii Emperor Han Wu was the emperor of Western Han Dynasty, 156-87 BC. 
v We thank an anonymous reviewer for this useful phrase on the subsequent distinctions. 